\title{
NATURALIZATION OF PLAINS COTTONWOOD (POPULUS DELTOIDES SUBSP. MONILIFERA) ALONG RIVER DRAINAGES WEST OF THE ROCKY MOUNTAINS
}

\author{
J.H. Braatne ${ }^{1}$, S.J. Brunsfeld ${ }^{2}$, V.D. Hipkins ${ }^{3}$, and B.L. Wilson ${ }^{3}$
}

\begin{abstract}
Historic botanical surveys documented that the natural distribution of the plains cottonwood (Populus deltoides subsp. monilifera) was limited to semiarid drainages east of the Rocky Mountains. Recently, a number of isolated populations of plains cottonwood have been found along the Kootenai, lower Snake, and Columbia Rivers and their tributaries. We used isozyme analysis to assess the genetic structure of these Pacific Northwest (PNW) populations in relation to native cottonwood populations east of the Rocky Mountains. These genetic data along with field surveys (dbh, age estimates) and cadastral field survey notes (mid-1800s) were used to understand the origin of these disjunct populations (i.e., relictual natives versus naturalized introductions). Genetic analyses revealed high levels of genetic diversity within and among PNW populations as well as hybridization with black cottonwood ( $P$. trichocarpa). The observed range of genetic variation for PNW populations was similar to that of native cottonwood populations. Collectively, these data confirm that these scattered populations are plains cottonwood (Populus deltoides subsp. monilifera). Age estimates of the largest individuals found within study populations ranged from 27 to 51 years. Cadastral field surveys also noted the absence of woody vegetation along the lower Snake and Columbia Rivers. Considered together, the data suggest that these populations are of recent origin. The high levels of observed genetic variation are consistent with the reproductive biology of Populus spp. (i.e., obligate outcrossing and widespread dispersal of pollen and seed by wind and water) and a recurrent introduction of plains cottonwood throughout the study area.
\end{abstract}

Key words: Populus deltoides subsp. monilifera, plains cottonwood, isozyme analysis, naturalization, Snake River, Kootenai River, Columbia River, cadastral field surveys.

Early western explorers, plant ecologists, and taxonomists documented that the natural distribution of the plains cottonwood (Populus deltoides subsp. monilifera) was limited to semiarid drainages east of the Rocky Mountains (Brayshaw 1965, 1996, Hitchcock and Cronquist 1973, Eckenwalder 1984, 1996; exploration and botanical surveys of Merriwether Lewis and William Clark [1804-1805]; Nathaniel Wyeth, Thomas Nuttall, and John Towsend [1833-1834]; John McLeod [1837]; John Fremont [1843-1847]; John Mullan [1853-1854]; William Raynolds [1859-1860]; and Ferdinand Hayden [1871-1872], among others [Cronquist et al. 1986]). However, several isolated populations of plains cottonwood (P. deltoides subsp. monilifera) were recently identified along the Kootenai, lower Snake, and Columbia Rivers and their tributaries (Fig. 1). These populations could be the result of either historic contractions or recent expansions of introduced trees (mid-1900s). These populations also appeared to contain individuals that had hybridized with black cottonwood (P. trichocarpa) and Lombardy poplar (P. nigra var. italica). The purpose of this study was to utilize field surveys (both recent and historic) along with isozyme analyses to explore the probable origin of these scattered populations of plains cottonwood. If isozyme analysis showed a low level of genetic variation, these populations were probably the result of a limited number of introduced genotypes. Alternatively, high levels of genetic variation within and among populations would lend support to either the presence of relictual populations or a more recent naturalized range extension of plains cottonwood.

\section{Methods}

Beginning in the 1980s, researchers, in search of breeding stock for the University of Washington-Washington State University Poplar Research Program (led by R.F. Stettler, H.D. Bradshaw, and P.E. Heilman), and private

\footnotetext{
${ }^{1}$ Department of Fish and Wildlife Resources, University of Idaho, Moscow, ID 83844. E-mail: braatne@uidaho.edu

${ }^{2}$ Department of Forest Resources, University of Idaho, Moscow, ID 83844.

${ }^{3}$ USDA Forest Service, National Forest Genetic Electrophoresis Laboratory, Placerville, CA 95667.
} 


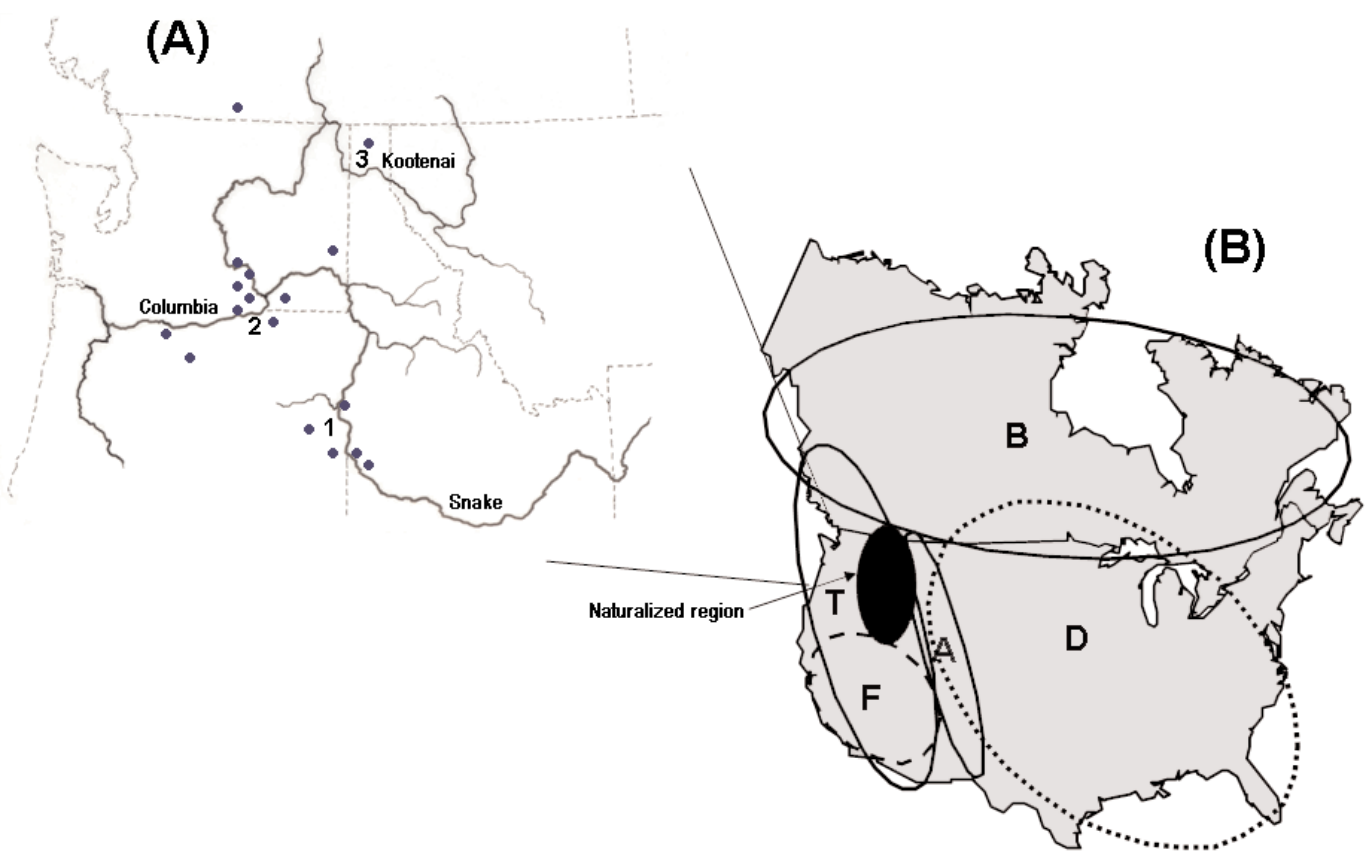

Fig. 1. (A) Map of study area and (B) distribution of Populus spp. in North America. $1=$ Ontario, OR; $2=$ Plymouth, WA; and $3=$ Bonners Ferry, ID. Small solid circles refer to locations of voucher specimens. $\mathrm{A}=$ P. angustifolia; $\mathrm{B}=P$. balsamifera; $\mathrm{D}=$ P. deltoides (vars. deltoides, monilifera, and wiselinzii); $\mathrm{F}=P$. fremontii; and $\mathrm{T}=$ P. trichocarpa.

companies (e.g., K. Wearstler, Boise Cascade Corporation) surveyed most drainages within the Columbia Basin for Populus spp. As a result, the locations of various $P$. deltoides populations were recorded for most of Oregon, Idaho, and Washington. This species was also commonly planted in city parks and gardens throughout the region (observations of R.F. Stettler, H.D. Bradshaw, J.H. Braatne, and S.J. Brunsfeld). In the late 1990s, age and size class were determined and genetic analyses were performed for several study populations (Fig. 1). Voucher specimens were collected for all populations, and their taxonomic identity as Populus deltoides subsp. monilifera was confirmed by T.C. Brayshaw and J.E. Eckenwalder. Specimens are now located in the University of Washington Herbarium (WTU), Seattle, Washington, and the University of Idaho Research Herbarium (IDF), Moscow, Idaho.

\section{Age and Size Class}

In each study population, 3-5 of the largest individuals were selected for age and size class measurements. All samples were collected during winter 2000. Size measurements were ob- tained with a Lufkin dbh tape (nearest $0.1 \mathrm{~cm}$ ). Tree cores were obtained with a Haglof increment borer $(5.15 \mathrm{~mm}, 72 \mathrm{~cm})$, mounted on wood blocks, and sanded with 400 grit sandpaper. Four independent ring counts were obtained for each core. We estimated tree age using these data and estimated the approximate time period of initial establishment for each population.

\section{Cadastral Field Survey Notes}

Cadastral field survey notes (i.e., public land surveys of the mid- to late 1800s) were obtained for the largest study populations (Columbia River, near Plymouth, WA; Snake River near Ontario, OR; and Kootenai River near Bonners Ferry, ID) from library collections at the Universities of Idaho and Washington. Appendix 1 contains an abbreviated summary of these field notes.

\section{Genetic Analysis}

Leaf samples for isozyme analyses were collected from populations growing along major rivers at various locations throughout the Pacific 
TABLE 1. Collection sites for cottonwood samples used in genetic analyses.

\begin{tabular}{|c|c|c|c|c|}
\hline Taxon & $\begin{array}{l}\text { Population } \\
\text { acronym }\end{array}$ & State & Location & Collector \\
\hline \multirow[t]{4}{*}{$\begin{array}{r}\text { Populus trichocarpa, } \\
\text { black cottonwood }\end{array}$} & $\mathrm{C}$ & OR & $\begin{array}{l}\text { Big Summer Ranger District, } \\
\text { Ochoco National Forest }\end{array}$ & D. Ecker \\
\hline & M & OR & Near Mitchell, Hwy 26, MP 67 & D. Ecker \\
\hline & $\mathrm{SA}$ & WA & Satus, Hwy 97, 15 miles south of Toppenish & D. Ecker \\
\hline & W & OR & $\begin{array}{l}\text { Santiam Pass, Hwy } 20 \text {, } \\
\text { Williamette National Forest }\end{array}$ & D. Ecker \\
\hline \multirow{3}{*}{$\begin{array}{l}\text { P. angustifolia, } \\
\text { narrowleaf cottonwood }\end{array}$} & $\mathrm{F}$ & OR & Fish Lake, Steens Mountain & D. Ecker \\
\hline & LAN & MT & Laurel, 20 miles east of Billings & L. Halstrom \\
\hline & PK & OR & $\begin{array}{l}\text { Burns District (BLM), west of } \\
\text { the Alvord Desert }\end{array}$ & P. Berrang \\
\hline \multirow{3}{*}{$\begin{array}{l}\text { P. fremontii, } \\
\text { Fremont's cottonwood }\end{array}$} & A & $\mathrm{AZ}$ & Near Flagstaff & J. Horton \\
\hline & $\mathrm{L}$ & $\mathrm{NV}$ & Lahantan near Reno & P. Berrang \\
\hline & $\mathrm{R}$ & $\mathrm{CA}$ & Red Bluff & P. Berrang \\
\hline \multirow{2}{*}{$\begin{array}{l}\text { P. deltoides var. deltoides, } \\
\text { eastern cottonwood }\end{array}$} & $\mathrm{N}$ & - $^{\mathrm{a}}$ & Clone bank, Upper Midwest & R. Hall \\
\hline & $\mathrm{K}$ & KY & Eastern Kentucky & R. Rousseau \\
\hline \multirow{3}{*}{$\begin{array}{l}\text { P. deltoides var. monilifera, } \\
\text { plains cottonwood }\end{array}$} & $\mathrm{CZ}$ & $\mathrm{NE}$ & Chadron, Halsey National Forest & M. Stein \\
\hline & LA & MT & Laurel, 18 miles east of Billings & P. Berrang \\
\hline & $\mathrm{PO}$ & MT & Laurel, 22 miles east of Billings & L. Halstrom \\
\hline \multirow[t]{5}{*}{ Pacific Northwest (PNW) } & $\mathrm{JJ}$ & OR & Jones Ranch near Juntura & L. Halstrom \\
\hline & $\mathrm{O}$ & OR & Owyhee, Ochoco National Forest & D. Ecker \\
\hline & $\mathrm{ON}$ & OR & Snake River near Ontario & D. Ecker \\
\hline & $\mathrm{P}$ & WA & Snake River near Plymouth & D. Ecker \\
\hline & SU & OR & Succor Creek, Vale District (BLM) & D. Ecker \\
\hline
\end{tabular}

aClone bank samples were originally collected from multiple states.

Northwest, Great Plains, desert Southwest, Midwest, and southern Mississippi River valley (Table 1). Leaves were collected from low branches or root sprouts of different trees (minimum distance of $10 \mathrm{~m}$ between sample trees). Samples were placed in plastic bags with wet paper towels and kept on ice in the field. All samples were healthy (with the exception of freezing damage on leaf samples from Nebraska) on arrival at the National Forest Genetic Electrophoresis Laboratory (Placerville, CA).

Sample Preparation.-Two discs $7 \mathrm{~mm}$ in diameter were placed in a microtiter plate well containing 3 drops of a Tris buffer $\mathrm{pH} 7.5$ (Gottlieb 1981), and the plates were frozen at $-70^{\circ} \mathrm{C}$. On the morning of the electrophoretic run, tissue samples were thawed and macerated in the buffer. Five 3-mm-wide wicks prepared from Whatman 3MM chromatography paper were saturated with the slurry, 3 were run, and the other 2 frozen as backups.

ElEctrophoresis.-Electrophoretic methods followed those of Conkle et al. (1982). The following enzymes were examined: diaphorase (DIA), fluorescent esterase (FEST), glutamateoxaloacetate transaminase (GOT), isocitrate de- hydrogenase (IDH), leucine aminopeptidase (LAP), malate dehydrogenase (MDH), malic enzyme (ME), phosphoglucomutase (pGM), phosphogluconate dehydrogenase (6PGD), phosphoglucose isomerase (PGI), triosephosphate isomerase (TPI), and uridine diphosphoglucosepyro-phosphorylase (UGPP). A total of 20 loci were resolved sufficiently for use in genetic analysis. A lithium borate electrode buffer ( $\mathrm{pH}$ 8.3) was used with a Tris citrate gel buffer ( $\mathrm{pH}$ 8.3) to resolve FEST-2, LAP-1, LAP-2, ME7, PGI-1, PGI-2 and PGM-1. A sodium borate electrode buffer ( $\mathrm{pH} 8.0)$ was used with a Tris citrate gel buffer ( $\mathrm{pH} 8.8)$ to resolve GOT-2, TPI-1, TPI-2, TPI-3, UGPP-1, and UGPP-2. A morpholine citrate electrode and gel buffer ( $\mathrm{pH}$ 8.0) was used to resolve DIA-1, IDH-1, MDH-1, MDH-2, 6PGD-1, 6PGD-2, and 6PGD-3. All enzymes were resolved on $11 \%$ starch gels. Stain recipes for enzymes also followed Conkle et al. (1982), except for GOT which was stained according to Wendel and Weeden (1989). Two people independently scored each gel. When results differed, a 3rd person resolved the conflict. For quality control, samples from $10 \%$ of the individuals were run and scored twice. 
DATA ANALYSIS.-Genetic interpretations were inferred directly from allozyme phenotypes and based on knowledge of the conserved enzyme substructure, compartmentalization, and isozyme number in higher plants (Gottlieb 1981, 1982, Weeden and Wendel 1989). These cottonwoods are considered diploid with 19 pairs of chromosomes (Smith 1943, Moldenke 1973, Larson 1986), and most isozyme loci showed diploid expression, but the genus may be diploidized ancient polyploids (Bialobok et al. 1976). In cottonwoods, most allozyme variants show Mendelian inheritance (Rajora 1990a, Muller-Starck 1992). We used Popgene version 1.21 (Yeh et al. 1997) to analyze results. A locus was considered polymorphic if an alternate allele occurred even once. Statistics included unbiased genetic distances (Nei 1978), expected heterozygozity (Nei 1973), expected number of alleles per locus (Kimura and Crow 1964), and gene flow $(\mathrm{Nm}=0.25[1 / \mathrm{Fs}] / \mathrm{Fst}$; Slatkin and Baron 1989). A dendrogram was generated in Popgene using UPGMA and Nei's unbiased genetic distances. F statistics (Wright 1978) for taxa were generated by BioSys-1, version 1.7 (Swofford and Selander 1989).

\section{REsUlts}

\section{Age and Size Class}

Though relatively large in size $(35-88 \mathrm{~cm}$ $\mathrm{dbh}$ ), all cored trees were quite young. Age estimates ranged from 22 years to 51 years, with the oldest trees (48-51 years) found at Bonners Ferry, Idaho, and the youngest trees (28-33 years) at Plymouth, Washington. No stumps, indicative of the earlier harvesting of older cottonwood trees, were observed in any of the study locations. These populations apparently were established from the 1950s through the 1970 s and are thus of recent origin.

\section{Cadastral Field Survey Notes}

The cadastral field survey notes and map plats from the mid- to late 1800 s recorded the general absence of "timber" and cottonwood along the lower Snake and Columbia Rivers (Appendix 1). Scattered clumps of native willow (presumably Salix exigua) were limited to backwater sloughs and river margins. Willows and other riparian shrubs were somewhat more abundant on the alluvial fans of side tributaries to the Columbia and Snake Rivers. In the late $1800 \mathrm{~s}$, black cottonwood (P. trichocarpa) was recorded along the Kootenai River, but not plains cottonwood. Since plant taxonomists, such as E.L. Ornsbee and E. Giddings, were members of these cadastral field survey crews, we can be relatively confident that, if plains cottonwood had been present, it would have been correctly identified.

\section{Genetic Analysis}

All populations were moderately variable (Table 2) with the exception of 2 plains cottonwood populations from Montana (LA and PO), 1 Fremont's cottonwood population from Nevada (L), and 1 PNW population (JJ). No fixed differences in allele presence coincided with species boundaries, but extreme differences in allele frequencies separated some taxa (e.g., 6PGD-2 and 6PGD-3; Appendix 2). Genetic distances between populations varied widely, but most populations of the same taxon had identities above 0.85 (Table 3).

Dendrograms based on Nei's genetic distances between populations divided the populations into 2 clusters (Fig. 2). One cluster contained black and narrowleaf cottonwoods (and the JJ population, see Discussion), and the 2nd contained Fremont's, eastern, plains, and PNW cottonwoods. In this larger 2nd cluster, populations of $P$. deltoides (both varieties) and PNW cottonwoods formed a single cluster that was closely aligned and clustered with Fremont's cottonwood populations.

Ten alleles (at 8 loci) were observed in PNW cottonwoods and not in other populations of $P$. deltoides (Table 4). Three of these alleles were unique to PNW cottonwoods, 2 were shared only with black cottonwood, and 5 were shared with black, narrowleaf, and Fremont's cottonwoods. With 2 exceptions, the alleles observed only in PNW populations were uncommon to rare in those populations. The PNW populations $\mathrm{ON}, \mathrm{P}$, and $\mathrm{SU}$ had high numbers of rare alleles (those with frequency <0.1; Appendix 2 ), and that remained true when alleles shared with species other than eastern or plains cottonwoods were removed from the analysis (data not shown).

As expected, more genetic variation was present among individuals within a population (Fis) than among populations of a taxon (Fst; Table 2). Inclusion of the divergent JJ population raised the Fst values in the PNW populations. 
TABLE 2. Summary of genetic diversity measures: Pop = population acronym; $\mathrm{N}=$ mean number of individuals sampled per locus per population; $\% \mathrm{P}=$ percent of all loci that were polymorphic; $\mathrm{A}=$ average number of alleles per locus; ne $=$ effective number of alleles (Kimura and Crow 1964); AP = average number of alleles per polymorphic locus; Ho = observed frequency of heterozygotes; He = frequency of heterozygotes expected under Hardy-Weinberg equilibrium conditions; Fis $=$ proportion of genetic variation found among individuals within a population; Fit $=$ proportion of genetic variation found among individuals within a taxon; Fst $=$ proportion of genetic variation found among populations within a taxon; $\mathrm{Nm}=$ calculated gene flow between populations within a taxon.

\begin{tabular}{|c|c|c|c|c|c|c|c|c|c|c|c|c|}
\hline Taxon & Pop & $\mathrm{N}$ & $\% \mathrm{P}$ & A & ne & $\mathrm{AP}$ & Ho & $\mathrm{He}$ & Fis & Fit & Fst & $\mathrm{Nm}$ \\
\hline All cottonwoods & & 619.0 & 95 & 3.1 & 1.64 & 2.64 & 0.102 & 0.301 & 0.289 & 0.679 & 0.548 & 0.197 \\
\hline \multirow[t]{5}{*}{ P. trichocarpa } & All & 136.0 & 75 & 2.3 & 1.50 & 2.62 & 0.146 & 0.260 & 0.313 & 0.443 & 0.189 & 1.085 \\
\hline & $\mathrm{C}$ & 38.0 & 50 & 1.6 & 1.30 & 2.20 & 0.143 & 0.178 & & & & \\
\hline & M & 27.0 & 55 & 1.8 & 1.35 & 2.36 & 0.120 & 0.199 & & & & \\
\hline & SA & 38.5 & 75 & 2.2 & 1.52 & 2.53 & 0.167 & 0.270 & & & & \\
\hline & W & 33.0 & 55 & 1.9 & 1.32 & 2.64 & 0.135 & 0.189 & & & & \\
\hline \multirow[t]{4}{*}{ P. angustifolia } & All & 62.5 & 65 & 2.1 & 1.59 & 2.69 & 0.155 & 0.268 & 0.061 & 0.430 & 0.394 & 0.382 \\
\hline & $\mathrm{F}$ & 32.0 & 45 & 1.6 & 1.39 & 2.33 & 0.174 & 0.189 & & & & \\
\hline & LAN & 4.5 & 30 & 1.4 & 1.25 & 2.33 & 0.115 & 0.141 & & & & \\
\hline & PK & 26.0 & 40 & 1.6 & 1.34 & 2.62 & 0.146 & 0.155 & & & & \\
\hline \multirow[t]{4}{*}{ P. fremontii } & All & 97.0 & 55 & 1.9 & 1.30 & 2.50 & 0.086 & 0.147 & 0.314 & 0.427 & 0.165 & 0.680 \\
\hline & A & 29.0 & 45 & 1.8 & 1.36 & 2.67 & 0.080 & 0.146 & & & & \\
\hline & $\mathrm{L}$ & 40.0 & 25 & 1.4 & 1.16 & 2.60 & 0.088 & 0.080 & & & & \\
\hline & $\mathrm{R}$ & 32.5 & 40 & 1.6 & 1.27 & 2.62 & 0.089 & 0.149 & & & & \\
\hline \multirow{3}{*}{$\begin{array}{l}\text { P. deltoides } \\
\text { var. deltoides }\end{array}$} & All & 68.5 & 60 & 2.0 & 1.43 & 2.67 & 0.077 & 0.219 & 0.532 & 0.648 & 0.248 & 0.760 \\
\hline & $\mathrm{N}$ & 37.0 & 50 & 1.9 & 1.37 & 2.80 & 0.096 & 0.175 & & & & \\
\hline & $\mathrm{K}$ & 31.5 & 45 & 1.8 & 1.29 & 2.67 & 0.054 & 0.155 & & & & \\
\hline \multirow{4}{*}{$\begin{array}{l}\text { P. deltoides } \\
\text { var. monilifera }\end{array}$} & All & 99.5 & 50 & 1.8 & 1.15 & 2.60 & 0.057 & 0.103 & 0.339 & 0.528 & 0.286 & 1.189 \\
\hline & $\mathrm{CZ}$ & 24.5 & 40 & 1.7 & 1.26 & 2.75 & 0.093 & 0.138 & & & & \\
\hline & LA & 39.0 & 30 & 1.4 & 1.11 & 2.17 & 0.044 & 0.071 & & & & \\
\hline & $\mathrm{PO}$ & 36.0 & 25 & 1.3 & 1.11 & 2.20 & 0.044 & 0.068 & & & & \\
\hline \multirow[t]{7}{*}{ PNW populations } & All & 132.0 & 80 & 1.2 & 1.43 & 2.81 & 0.091 & 0.236 & 0.297 & 0.629 & 0.472 & 0.312 \\
\hline & No JJ & 113.0 & 80 & 2.4 & 1.32 & 2.18 & 0.080 & 0.180 & 0.455 & 0.569 & 0.210 & 1.143 \\
\hline & $\mathrm{JJ}$ & 19.0 & 20 & 1.3 & 1.18 & 2.50 & 0.150 & 0.087 & & & & \\
\hline & $\mathrm{O}$ & 29.0 & 40 & 1.6 & 1.29 & 2.62 & 0.078 & 0.164 & & & & \\
\hline & $\mathrm{ON}$ & 38.0 & 55 & 1.8 & 1.25 & 2.45 & 0.075 & 0.142 & & & & \\
\hline & $\mathrm{P}$ & 39.0 & 75 & 2.4 & 1.27 & 2.80 & 0.087 & 0.174 & & & & \\
\hline & $\mathrm{SU}$ & 7.0 & 40 & 1.6 & 1.14 & 2.38 & 0.071 & 0.105 & & & & \\
\hline
\end{tabular}

TABLE 3. Nei's (1978) unbiased genetic distances between cottonwood taxa (maximum [top number] and minimum [bottom number]). "No JJ" means without population JJ, which was removed because of its highly unusual allele frequencies.

\begin{tabular}{|c|c|c|c|c|c|c|c|}
\hline & Black & Narrow & Fremont's & Eastern & Plains & PNW & PNW, no JJ \\
\hline \multirow[t]{2}{*}{ Black } & 0.9638 & 0.8706 & 0.7309 & 0.7891 & 0.7836 & 0.8366 & 0.8366 \\
\hline & 0.9033 & 0.7875 & 0.6466 & 0.7510 & 0.7510 & 0.6973 & 0.7466 \\
\hline \multirow[t]{2}{*}{ Narrow } & & 0.8860 & 0.9202 & 0.7708 & 0.7326 & 0.8278 & 0.8026 \\
\hline & & 0.7334 & 0.6561 & 0.6234 & 0.6548 & 0.6642 & 0.6642 \\
\hline \multirow[t]{2}{*}{ Fremont's } & & & 0.9602 & 0.9027 & 0.9202 & 0.9360 & 0.9360 \\
\hline & & & 0.8858 & 0.5678 & 0.7943 & 0.6864 & 0.7856 \\
\hline \multirow[t]{2}{*}{ Eastern } & & & & 0.8737 & 0.9861 & 0.9597 & 0.9597 \\
\hline & & & & 0.8087 & 0.7027 & 0.4734 & 0.6426 \\
\hline \multirow[t]{2}{*}{ Plains } & & & & & 0.9996 & 0.9718 & 0.9718 \\
\hline & & & & & 0.9101 & 0.5759 & 0.8561 \\
\hline \multirow[t]{2}{*}{ PNW } & & & & & & 0.9721 & - \\
\hline & & & & & & 0.6587 & - \\
\hline \multirow[t]{2}{*}{ PNW, no JJ } & & & & & & & 0.9721 \\
\hline & & & & & & & 0.8905 \\
\hline
\end{tabular}




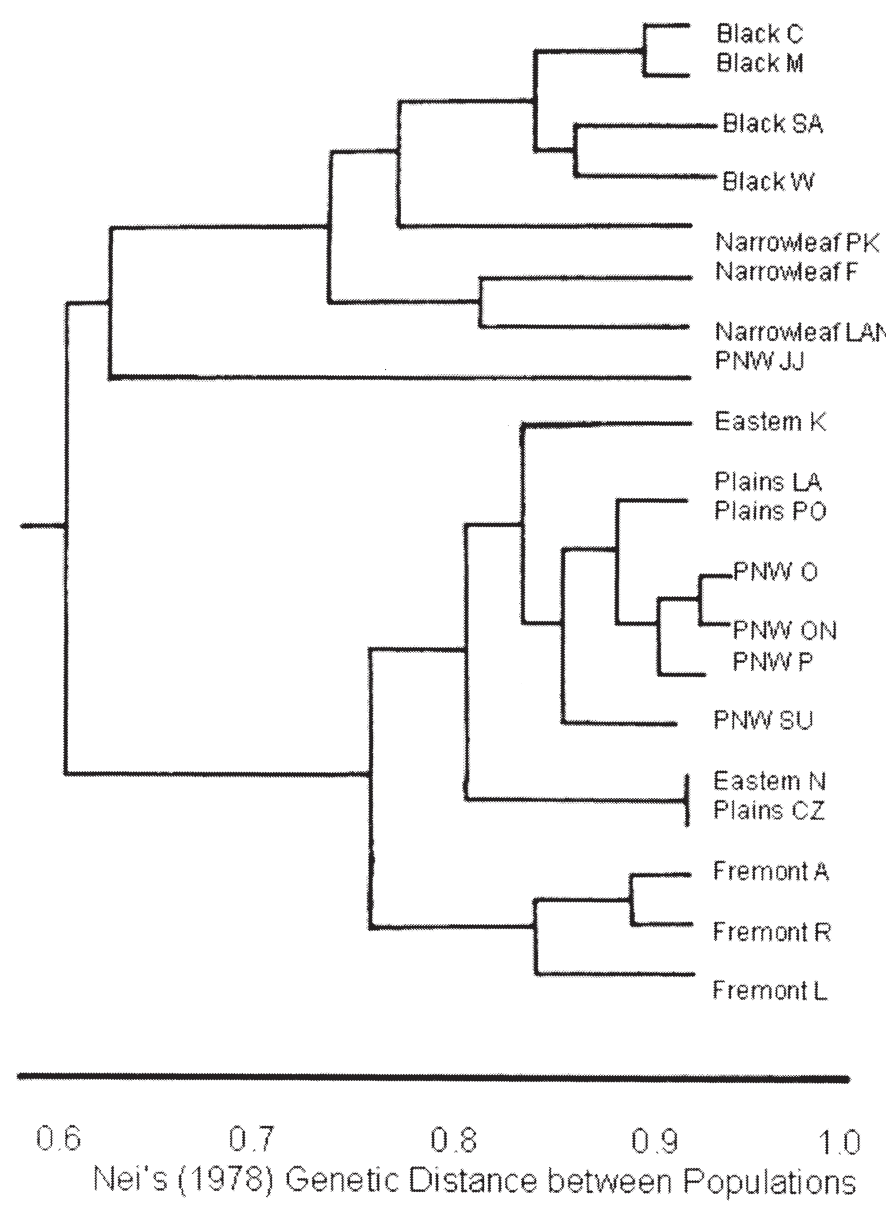

Fig. 2. Dendrogram of allozyme similarity between cottonwood samples, based on Nei's unbiased genetic identities (Nei 1978)

Complete multilocus data were produced for 402 individuals (Popgene 1.2.1), with a varied distribution of identical multilocus genotypes (possible clones) among sampled populations. In 267 cases (66\%), a given multilocus genotype was represented by a single individual in a population. The mean number of individuals per possible clone was $<3$ in all populations. Eleven $(78 \%)$ of the 14 possible clones consisted of 3 or more samples and these occurred in just 3 of the populations (Plains LA, Plains PO, and Fremont's L; data not shown).

\section{Discussion}

Age and Size Class and Cadastral Field Survey Notes

Results obtained from age and size class determinations and cadastral survey notes strongly suggest a recent origin for $P$. deltoides populations along the Kootenai, lower Snake, and Columbia Rivers. The relatively rapid rate of naturalization by other nonnative woody species, such as European willows (S. alba, Salix $x$ rubens), false indigo (Amorpha fruticosa), Russian olive (Eleagnus angustifolia), and salt cedar (Tamarix complex), along rivers of the Intermountain West has also been independently observed by a number of botanists (observations of R. Mack, R. Stettler, F.D. Johnson, T.C. Brayshaw, S. and P. Brunsfeld, and J.H. Braatne). Similar patterns have been reported for a number of nonnative woody plants throughout the southwestern U.S. (observations of P. Shafroth, D. Patten, J. Stromberg, and L. Stevens). Widespread planting of plains cottonwood in city parks and recreation areas 
TABLe 4. Alleles detected in PNW cottonwoods, but not in other P. deltoides samples.

\begin{tabular}{lcccl}
\hline Locus & Allele & Population & Frequency & \multicolumn{1}{c}{ Comment } \\
\hline DIA-1 & 3 & $\mathrm{P}$ & 0.0500 & Also occurs in black, narrowleaf and Fremont's cottonwoods \\
FEST-2 & 4 & $\mathrm{O}$ & 0.1034 & Not observed in other taxa \\
& & $\mathrm{P}$ & 0.0395 & \\
IDH-1 & 3 & $\mathrm{P}$ & 0.0875 & Also occurs in black cottonwood \\
& 4 & $\mathrm{P}$ & 0.0750 & Not observed in other taxa \\
LAP-2 & 2 & $\mathrm{JJ}$ & 1.0000 & Also occurs in black, narrowleaf and Fremont's cottonwoods \\
& & ON & 0.0538 & \\
& & $\mathrm{P}$ & 0.0152 & \\
6PGD-1 & 3 & $\mathrm{SU}$ & 0.9286 & \\
& & $\mathrm{JJ}$ & 0.5000 & Also occurs in black, narrowleaf and Fremont's cottonwoods \\
TPI-1 & 6 & $\mathrm{O}$ & 0.1379 & \\
& & $\mathrm{ON}$ & 0.0128 & Not observed in other taxa \\
UGPP-1 & 2 & $\mathrm{P}$ & 0.0250 & \\
& & $\mathrm{JJ}$ & 0.5000 & Also occurs in black, narrowleaf and Fremont's cottonwoods \\
& & $\mathrm{P}$ & 0.0256 & \\
UGPP-2 & 3 & $\mathrm{JJ}$ & 0.5000 & Also occurs in black cottonwood \\
\hline
\end{tabular}

throughout the Columbia Basin has provided multiple sources for additional establishment at nearby rivers. It would thus appear reasonable to infer that $P$. deltoides subsp. monolifera has recently become naturalized along major rivers (and their tributaries) west of the Rocky Mountains.

\section{Patterns of Genetic Variation}

This study showed higher levels of genetic diversity than previous studies (Weber and Stettler 1981, Rajora 1989, 1990a, 1990b, Rajora and Zsuffa 1990). Our results differ from studies by Rajora (1989, 1990a, 1990b) and Rajora and Zsuffa (1990) because their research was not specifically designed to assess genetic diversity of wild populations. Sample sizes in previous studies of eastern cottonwood were also lower. The study of black cottonwood by Weber and Stettler (1981) included larger sample sizes and more populations but was confined to a climatically more homogeneous region west of the Cascades (resulting in less interpopulation variation). In contrast our study sampled a wide range of climatic and environmental regimes.

Population genetic variability was similar to that of other long-lived woody plants at both the species and the population level (Hamrick and Godt 1992). Genetic distances between conspecific plant populations usually exceed 0.9 (Crawford 1990); this was true for most of the cottonwood taxa (Table 3). However, conspecific populations of eastern and narrowleaf cottonwoods were more distinct than expected (Table 3).

\section{Identification and Taxonomy}

Allozyme data defined groups that were consistent with established cottonwood taxonomy. Black and narrowleaf cottonwood are in section Tacamahaca Spach; and Fremont's, eastern, and plains cottonwood are in section Aigeiros Duby (Krussman 1977, Eckenwalder 1996). These 2 sections coincided with the 2 clusters of populations identified with allozymes (Fig. 2). However, no fixed allozyme differences between cottonwood species were observed (Fig. 2). Therefore, the PNW cottonwood is $P$. deltoides, not an isolated population of Fremont's cottonwood (Fig. 2). Isozyme frequencies did not support the traditional taxonomy within $P$. deltoides. They failed to differentiate the sampled populations of $P$. deltoides var. deltoides from Midwestern populations of $P$. deltoides var. occidentalis. (The latter taxon is now referred to as $P$. deltoides subsp. monilifera.) The southern sample of $P$. deltoides var. deltoides, collected in and near the delta of the Mississippi River, was highly divergent. However, the genetic distance between the Nebraska population (P. deltoides var. occidentalis) and the north Midwestern sample of $P$. deltoides var. deltoides was 0.9861 , the highest value found 
in this study (Table 3). A previous isozyme study also showed a lack of differentiation between populations of $P$. deltoides var. deltoides and $P$. deltoides var. occidentalis (Rajora 1989). Morphologically the 2 varieties are confluent over a large area of the eastern Plains and upper Midwest (Gleason and Cronquist 1991, Eckenwalder 1996). The close genetic relationship between the sample from Nebraska and that from clones gathered from the upper Midwest apparently reflects the biology of these trees more closely than their nomenclature would suggest.

\section{Introgression and Asexual Reproduction}

Ten alleles occurring in the PNW populations were observed in no other $P$. deltoides population (Table 4). Seven of these alleles were also present in black cottonwood, and some of them were present in narrowleaf and Fremont's cottonwood. Plains cottonwood hybridizes naturally with all sympatric species of Populus, including black and narrowleaf cottonwood, though cottonwood hybrids are usually less fertile (Smith 1943, Brayshaw 1965, 1996, Eckenwalder 1996). Perhaps these 7 alleles were introduced into PNW populations of $P$. deltoides subsp. monilifera via introgression with black cottonwood. Given the location of PNW populations within the central range of black cottonwood, this level of introgression is not unexpected.

Given the tree-to-tree variation, we judged that most cottonwoods sampled resulted from sexual reproduction rather than clonal spread. In fact, the number of genetic individuals may be greater than the reported number of multilocus genotypes because the samples may differ at loci not studied. The low number of individuals per genotype is consistent with the observation that, although cottonwoods sprout readily from stumps or root crowns, they rarely spread clonally by suckers (Zsuffa 1976). This contrasts with quaking aspen (Populus tremuloides Michx.) in which single clones may cover many acres and include dozens or hundreds of stems (Kemperman and Barnes 1976).

The PNW population JJ differed significantly from other populations. This uniformly distributed population occupied about 0.4 ha along an abandoned railroad, and the subset sampled came from an area of $<0.1$ ha. Its allozyme pattern did not cluster with other PNW cottonwood populations (Fig. 2), and 16 of the 19 trees shared a single multilocus genotype, most likely the result of vegetative reproduction. Four alleles observed in all samples from population $\mathrm{JJ}$ are present in other species but not in any other sampled populations of $P$. deltoides. The sampled JJ population appeared to consist of a single clone, which was probably a hybrid between $P$. deltoides and either black or narrowleaf cottonwood, or the descendant of such a hybrid. This stand appears to exhibit higher levels of clonal reproduction than any other sampled population.

\section{Origins of Plains \\ Cottonwood Populations in the Pacific Northwest}

The PNW populations were genetically variable and most closely related to the plains cottonwood populations from Montana (populations LA and PO; Fig. 2). Thus, allozyme data suggest that PNW populations were either native or the result of multiple introductions from populations east of the Rocky Mountains. If PNW populations originated from deliberate introductions, they were limited to sources west of the Mississippi River. Isozyme analysis alone cannot rule out contrasting hypotheses that the PNW plains cottonwoods were introduced or were native. In fact, it may be appropriate to complement this genetic analysis with studies using chloroplast DNA (cpDNA), an emerging tool for studying historical phylogenetic lineages (Cottrell et al. 2005). However, when allozyme data are combined with other data sources (i.e., field surveys, cadastral field notes, and documentation of a lack of extensive hybrid swarms), these regional populations of plains cottonwood appear to be of recent origin. Their high levels of genetic diversity reflect the reproductive biology of Populus spp. (i.e., obligate outcrossing and wind or water dispersal of pollen and seed; Braatne et al. 1996) and would be perpetuated via both natural or human-assisted spread. Given its suite of morphological and physiological adaptations to arid climates (Braatne et al. 1992, 1996), plains cottonwood should also continue to expand its range throughout the lower Columbia and Snake River basins. Researchers and taxonomists should thus be aware of the naturalization of the plains cottonwood (Populus deltoides var. monilifera) along river drainages west of the Rocky Mountains. 


\section{ACKNOWLEDGMENTS}

Research activities and data analyses were supported financially by the USDA Forest Service (Regions 6 and 9), UW/WSU Poplar Research Program, Boise Cascade, and University of Idaho. We give special thanks to $\mathrm{P}$. Berrang, D. Ecker, S. Gage, L. Halstrom, J. Horton, R. Hall, M. Stein, R. Rousseau, and our research crews (Mathea Braatne, Bob Jamieson, Mary-Louise Polzin, and Greg Cook, among others) for assisting with the field collection and storage of plant materials. Thanks go to Patricia Guge and Randy Meyer for technical assistance in the laboratory. The manuscript also benefitted greatly from reviews provided by R.F. Stettler and 4 anonymous reviewers.

\section{Literature Cited}

Bialobok, S., W. Bugala, A. Hejnowicz, T. Jakuszewski, L.S. Jankiewicz, Z. Obmillski, R. Siwecki, et AL. 1976. The poplars-Populus L. U.S. Department of Agriculture and National Science Foundation, Washington, DC. (Translation by H. Markiewicz of Nasze Drzewa Lesne Monografie Popularnownaukowe, Volume 12, 1973, pages 1-515.)

Braatne, J.H., T.M. Hinckley, and R.F. Stettler. 1992. Influence of soil water on the physiological and morphological components of plant water balance in Populus trichocarpa, Populus deltoides and their $\mathrm{F}_{1}$ hybrids. Tree Physiology 11:325-340.

Braatne, J.H., S.B. Rood, and P.E. Heilman. 1996. Life history, ecology and conservation of riparian cottonwoods in North America. Pages 57-85 in R.F. Stettler, H.D. Bradshaw, Jr., P.E. Heilman, and T.M. Hinckley, editors, Biology of Populus and its implications for management and conservation. NRC Research Press, National Research Council of Canada, Ottawa, Ontario.

BrayshaW, T.C. 1965. Native poplars of southern Alberta and their hybrids. Canada Department of Forestry Publication 1109:1-40.

1996. Catkin-bearing plants of British Columbia. Royal British Columbia Museum Press, Victoria, British Columbia, Canada.

Conkle, M.T., P.D. Hodgskiss, L.B. Nunnally, and S.C. HunTER. 1982. Starch gel electrophoresis of conifer seeds: a laboratory manual. General Technical Report PSW-64, Pacific Southwest Forest and Range Experiment Station, USDA Forest Service, Berkeley, CA. $18 \mathrm{pp}$.

Cottrell, J.E., V. Krystufek, H.E. Tabbener, A.D. MilNer, T. Connolly, L. Sing, S. Fluch, ET AL. 2005. Postglacial migration of Populus nigra L.: lessons learnt from chloroplast DNA. Forest Ecology and Management 206:71-90.

Crawford, D.J. 1990. Plant molecular systematics: macromolecular approaches. John Wiley \& Sons, New York.

Cronquist, A., A.H. Holmgren, N.H. Holmgren, AND J.L.
REVEAL. 1986. Intermountain flora: vascular plants of the Intermountain West, USA. Volume 1. Geological and botanical history of the region, its plant geography and a glossary. The New York Botanical Garden, Bronx, NY.

ECKENWALDER, J.E. 1984. Natural intersectional hybridization between North American species of Populus (Salicaceae) in sections Aigerios and Tacamahaca. II. Taxonomy. Canadian Journal of Botany 62:325-335.

. 1996. Systematics and evolution of Populus. Pages 7-32 in R.F. Stettler, H.D. Bradshaw, Jr., P.E. Heilman, and T.M. Hinckley, editors, Biology of Populus and its implications for management and conservation. Part I, Chapter 1. NRC Research Press, National Research Council of Canada, Ottawa, Ontario.

Gleason, H.A., AND A. ConQuest. 1991. Manual of vascular plants of the northeastern United States and adjacent Canada. The New York Botanical Garden, Bronx, NY.

Gottlieb, L.D. 1981. Gene number in species of Asteraceae that have different chromosome numbers. Proceedings. National Academy of Sciences. United States of America 78:3726-3729.

. 1982. Conservation and duplication of isozymes in plants. Science 216:373-380.

Hamrick, J.L., M.J.W. GodT, and S.L. Sherman-Broyies. 1992. Factors influencing levels of genetic diversity in woody plant species. Pages 94-124 in W.T. Adams, S.H. Strauss, D.L. Copes, and A.R. Griffin, editors, Population genetics of forest trees. Kluwer Academic Publishers, Boston, MA.

Hitchcock, C.L., And A. Cronquist. 1973. Flora of the Pacific Northwest. University of Washington Press, Seattle.

Kemperman, J.A., and B.V. Barnes. 1976. Clone size in American aspens. Canadian Journal of Botany 54: 2603-2607.

Kimura, M., AND J.F. Crow. 1964. The number of alleles that can be maintained in a finite population. Genetics 49:725-738.

Krussman, G. 1977. Manual of cultivated broad-leaved trees and shrubs. II. E-Pro. M.E. Epp. translator. Timber Press, Portland, OR.

LARSON, G.E. 1986. Salicaceae Mirb., the willows. Pages 273-291 in T. Barkley, editor, Flora of the Great Plains. Great Plains Flora Association, University Press of Kansas, Lawrence.

Moldenke, A.R. 1973. A contribution to a chromosome atlas of the California flora. Technical Report 73-23, Part 2, Board of Studies in Biology, University of California.

Muller-Starck, G. 1992. Genetic control and inheritance of isoenzymes in poplars of the Tacamahaca section and hybrids. Silvae Genetica 41:87-95.

NEI, M. 1973. Analysis of gene diversity in subdivided populations. Proceedings. National Academy of Sciences. United States of America 70:3321-3323.

. 1978. Estimation of average heterozygosity and genetic distance from a small number of individuals. Genetics 89:583-590.

RAJORA, O.P. 1989. Genetic structure and identification of Populus deltoides clones based on allozymes. Genome 32:440-448.

1990a. Genetics of allozymes in Populus deltoides Marsh., P. nigra L., and P. maximowiczii Henry. Journal of Heredity 81:301-308.

1990b. Marker allozyme genes and alleles for dif- 
ferentiation of Populus deltoides, P. nigra, P. maximowiczii, and their interspecific hybrids. Canadian Journal of Botany 68:990-998.

Rajora, O.P., AND L. Zsuffa. 1990. Allozyme divergence and evolutionary relationships among Populus deltoides, P. nigra, and P. maximowiczii. Genome 33: 44-49.

Slatkin, M., and N.H. Barton. 1989. A comparison of three indirect methods for estimating average levels of gene flow. Evolution 43:1349-1368.

SMITH, E. 1943. A study of ecology and speciation in the genus Populus L. J. Arnold Arboretum 24:275-304.

Swofford, D.L., and R.B. Selander. 1989. BioSys-1, release 1.7. Illinois Natural History Survey, Champaign, IL.

WEBER, J.C., AND R.F. STETTLER. 1981. Isozyme variation among ten populations of Populus trichocarpa Torr. et. Gray in the Pacific Northwest. Silvae Genetica 30:82-87.

Wendel, J.F., And N.F. WeEden. 1989. Visualization and interpretation of plant isozymes. Pages 5-45 in D.E.
Soltis and P.S. Soltis, editors, Isozymes in plant biology. Dioscorides Press, Portland, OR.

Wright, S. 1978. Evolution and the genetics of populations. Volume 4. Variability within and among natural populations. University of Chicago Press, Chicago, IL.

YeH, F.C., R.-C. Yang, T. Boyle, Z.H. Ye, and J.X. MaO. 1997. Popgene, the user friendly shareware for population genetic analysis, version 1.20. Molecular Biology and Biotechnology Centre, University of Alberta, Edmonton, Alberta, Canada.

ZsufFA, L. 1976. Vegetative propagation of cottonwood by rooting cuttings. Pages 99-108 in B.A. Thielges and S.B. Land, Jr., editors, Proceedings: symposium on eastern cottonwood and related species. Louisiana State University, Division of Continuing Education. Baton Rouge.

Received 12 May 2005

Accepted 2 December 2005

APPENDIX 1. Summary of cadastral field survey notes and plats (1867-1914) for the lower Snake, Columbia (Oregon and Washington) and Kootenai Rivers (Idaho).

Notes for Columbia River near Plymouth, Washington (T5N, R28E; T6N, R28E and R29E)

16 March1867-22 April 1867; Surveyors: E. Giddings, Z.T. Hays, H.M. Jefferds, and E.L. Ornsbee.

General description of T5N, R28E: Uplands rolling with "2nd rate soil, scattered basaltic columns, good grass with sage, prickly pear and sunflowers." River bottoms with "1st rate soil (some sand), with tall grasses and wild rye near backwater sloughs." Willow was typically "scarce with isolated small \& scattered populations along the river," though sections 1 and 2 were noted as containing "some few hundred willow near the river margin."

General description of T6N, R28E and R29E: "Both townships ( 5 \& 6) are covered with nutritious bunchgrasses, which are considered best for grazing purposes. Large bands of horses and cattle are now grazing these townships. ... . Uplands are generally rolling with rather poor to 2nd rate soil. The bottomlands near the Columbia River have good soil with several areas under cultivation." Common species include: "wild sage, rye, bunchgrasses, prickly pear and sunflower" on the uplands and "tall grasses, wild rye and some willows" in sloughs and along the river margin.

\section{Notes for Snake River Plain near Ontario, Oregon (T8N, R5W)}

31 March1868-5 October 1868; Surveyors: Allen Thompson, D. Allison, S.A. Steele.

"This township contains a fair proportion of rich bottom land good for farming situated on Snake River ... No timber along banks of Snake River."

24 November 1914; Surveyor: Basil C. Perkins.

"There is a sparse growth of cottonwood and willow and shrub undergrowth, principally in the immediate vicinity on banks of Snake River." Tree dbh: black willows 8 in and 11 in.

Notes for Kootenai River near Bonners Ferry, Idaho (T63N, R1W; T62N, R1E)

8 August 1893-28 August 1893; Surveyor: Frederick J. Mills.

T63N, R1W, Sec. 1 and Sec. 36: "Black cottonwood timber and dense undergrowth of thorn and willow in river bottom" Tree dbh: Black cottonwood 28 in, Tamarack 22 in, Birch 4 in, and Bearberry 3.5 in.

T62N, R1W, Sec. 1 and Sec. 12: Timber, cottonwood, fir, and cedar with dense undergrowth of willows and hawthorne with areas of dense impassible marsh. Tree dbh: Black cottonwood 42 in, 12 in, Bearberry 4 in. 
APPENDIX 2. Isozyme allele frequencies for study populations.

\begin{tabular}{|c|c|c|c|c|c|c|c|}
\hline Locus & Allele & Black & Narrow & Fremont's & Eastern & Plains & PNW \\
\hline DIA-1 & 1 & 0.9915 & 0.9853 & 0.9953 & 1.000 & 1.000 & 0.9851 \\
\hline DIA-1 & 3 & 0.0085 & 0.0147 & 0.0047 & & & 0.0149 \\
\hline FEST-2 & 1 & 0.4000 & 0.1419 & 0.6604 & 0.3178 & 0.9636 & 0.4361 \\
\hline FEST-2 & 2 & 0.0400 & 0.0811 & 0.3396 & & 0.0364 & 0.0301 \\
\hline FEST-2 & 3 & 0.5600 & 0.7770 & & 0.6822 & & 0.5000 \\
\hline FEST-2 & 4 & & & & & & 0.0338 \\
\hline GOT-2 & 1 & 0.4062 & 0.4110 & 0.6840 & 0.1682 & 0.8287 & 0.7857 \\
\hline GOT-2 & 2 & 0.1667 & 0.5753 & 0.2642 & 0.7944 & 0.1574 & 0.1579 \\
\hline GOT-2 & 3 & 0.4236 & 0.0137 & 0.0519 & 0.0374 & 0.0139 & 0.0564 \\
\hline GOT-2 & 4 & 0.0035 & & & & & \\
\hline IDH-1 & 1 & 0.9898 & 1.0000 & 1.0000 & 1.0000 & 1.0000 & 0.9662 \\
\hline IDH-1 & 3 & 0.0102 & & & & & 0.0263 \\
\hline IDH-1 & 4 & & & & & & 0.0075 \\
\hline LAP-1 & 1 & 0.0403 & 0.0278 & 0.8654 & 0.9673 & 1.0000 & 0.7969 \\
\hline LAP-1 & 2 & & 0.0278 & 0.1346 & 0.0140 & & 0.0078 \\
\hline LAP-1 & 3 & 0.9597 & 0.9444 & & 0.0187 & & 0.1953 \\
\hline LAP-2 & 1 & 0.7876 & 0.4247 & 0.8654 & 1.0000 & 1.0000 & 0.7480 \\
\hline LAP-2 & 2 & 0.2124 & 0.5753 & 0.1346 & & & 0.2520 \\
\hline MDH-1 & 1 & 0.2267 & 0.3846 & & 0.2692 & 0.0409 & 0.2331 \\
\hline MDH-1 & 2 & 0.7733 & 0.6154 & 0.0377 & 0.6731 & 0.5955 & 0.4699 \\
\hline MDH-1 & 3 & & & 0.9623 & 0.577 & 0.3636 & 0.2970 \\
\hline MDH-2 & 1 & 0.8245 & 1.0000 & 1.0000 & 1.0000 & 1.0000 & 1.0000 \\
\hline MDH-2 & 2 & 0.1755 & & & & & \\
\hline ME7 & 1 & 1.0000 & 1.0000 & 1.0000 & 1.0000 & 1.0000 & 1.0000 \\
\hline 6PGD-1 & 1 & & 0.0299 & 1.0000 & 0.0990 & & 0.5261 \\
\hline 6PGD-1 & 2 & 1.0000 & 0.9701 & & 0.0050 & 0.9352 & 0.4366 \\
\hline 6PGD-1 & 3 & & & & 0.7228 & 0.0648 & 0.0373 \\
\hline 6PGD-1 & 4 & & & & 0.1733 & & \\
\hline 6PGD-2 & 1 & 0.8203 & 0.5000 & 1.0000 & 1.0000 & 1.0000 & 1.0000 \\
\hline 6PGD-2 & 5 & 0.0938 & 0.3947 & & & & \\
\hline 6PGD-2 & 9 & 0.0859 & 0.1053 & & & & \\
\hline 6PGD-3 & 2 & & & 0.9294 & 1.0000 & 1.0000 & 0.7985 \\
\hline 6PGD-3 & 3 & 0.3386 & 0.5000 & 0.0706 & & & 0.2015 \\
\hline 6PGD-3 & 4 & 0.1417 & 0.5000 & & & & \\
\hline 6PGD-3 & 9 & 0.5197 & & & & & \\
\hline PGI-1 & 1 & 1.0000 & 1.0000 & 1.0000 & 0.9533 & 1.0000 & 1.0000 \\
\hline PGI-1 & 2 & & & & 0.0467 & & \\
\hline PGI-2 & 1 & 0.0136 & 0.1849 & 0.4524 & 0.5000 & 0.8738 & 0.6750 \\
\hline PGI-2 & 2 & 0.0340 & 0.0411 & 0.0286 & 0.0524 & 0.0093 & 0.0125 \\
\hline PGI-2 & 3 & 0.7109 & 0.4111 & 0.1333 & 0.1333 & 0.0093 & 0.1625 \\
\hline PGI-2 & 4 & 0.1565 & 0.0959 & 0.1762 & 0.1810 & 0.0327 & 0.1375 \\
\hline PGI-2 & 6 & 0.0850 & 0.2603 & 0.0810 & 0.1286 & 0.0748 & 0.0125 \\
\hline PGI-2 & 7 & & 0.0068 & 0.0429 & & & \\
\hline PGI-2 & 8 & & & 0.0857 & 0.0048 & & \\
\hline PGM-1 & 1 & 0.6652 & 0.4205 & 0.8030 & $\begin{array}{l}0.6040 \\
0.6579\end{array}$ & 0.9709 & 0.9286 \\
\hline PGM-1 & 2 & 0.3342 & 0.5795 & 0.1970 & 0.3289 & 0.0291 & 0.0188 \\
\hline PGM-1 & 4 & & & & 0.0132 & & 0.0526 \\
\hline TPI-1 & 1 & 0.8818 & 1.0000 & 1.0000 & 0.8643 & 0.9500 & 0.9888 \\
\hline TPI-1 & 2 & 0.1182 & & & 0.1357 & 0.0455 & \\
\hline TPI-1 & 3 & & & & & 0.0045 & \\
\hline TPI-1 & 4 & & & & & & 0.0112 \\
\hline TPI-2 & 1 & 1.0000 & 1.0000 & 1.0000 & 0.9859 & 0.8818 & 0.9664 \\
\hline TPI-2 & 9 & & & & 0.0141 & 0.1182 & 0.0336 \\
\hline TPI-3 & 2 & 1.0000 & 1.0000 & 1.0000 & 0.5667 & 0.7727 & 0.9242 \\
\hline TPI-3 & 3 & & & & 0.4333 & 0.2273 & 0.0758 \\
\hline UGPP-1 & 1 & 0.6954 & 0.7465 & 0.9906 & 1.0000 & 1.0000 & 0.8459 \\
\hline UGPP-1 & 2 & 0.2881 & 0.2535 & 0.0094 & & & 0.0789 \\
\hline UGPP-1 & 3 & 0.0132 & & & & & \\
\hline UGPP-1 & 4 & 0.0033 & & & & & 0.0752 \\
\hline UGPP-2 & 1 & 0.0300 & 0.1587 & 0.8734 & 0.5303 & 0.0602 & 0.1240 \\
\hline UGPP-2 & 2 & 0.6233 & 0.4365 & 0.1162 & 0.4697 & 0.9398 & 0.7868 \\
\hline UGPP-2 & 3 & 0.3467 & 0.4048 & 0.0404 & & & 0.0891 \\
\hline
\end{tabular}

